\title{
Political ecologies of wood and wax: sandalwood and beeswax as symbols and shapers of customary authority in the Oecusse enclave, Timor
}

\author{
Laura S. Meitzner Yoder ${ }^{1}$ \\ Goshen College, USA
}

\section{Introduction: the centrality of beeswax and sandalwood in forest regulation}

In conversations with villagers about forest regulation in the Oecusse enclave, Timor Leste, two historically important forest trade products on the island of Timor emerge: sandalwood (Santalum sp.) and beeswax. Western Timor was a hub for the lucrative trade in sandalwood and beeswax from the twelfth century onwards. ${ }^{2}$ Today, both commodities are still produced, from forest types that have been severely depleted elsewhere on the island. The primary reasons given for the protection afforded the extant forests in Oecusse are their critical role in fulfilling ritual obligations to the two local kings-especially that of providing beeswax for the kings' Easter candles - and long-standing norms restricting the harvest of sandalwood. ${ }^{3}$ These local traditions, which have continued to exist in the face of centuries of resource exploitation, are the central focus of this article. Drawing on ethnographic research, I trace how these forest products came to have their present symbolic value at the local level, the role that wood and wax have played in shaping the customary authorities present in modern Oecusse, and how each product's ecology relates to its tenure regime. The article contends that resource ecology, and concomitant possibilities of customary leaders' economic control, contributed to the commodity-specific constellations of authority and ownership practices that still exist today. In turn, local customary hierarchies have retained control over resources as a cultural anchor, through complex political transitions that have included regional trade links, Portuguese political control beginning in the mid 1500s, Indonesian occupation, and political independence since 1999. This constellation of power, resource control and ecologies constitute a 'political ecology of wood and wax'.

\section{Border conflicts over wood and wax}

The enclave District of Oecusse-Ambeno, Timor Leste, occupies $815 \mathrm{~km}^{2}$ on the north coast of western Timor island, with a current population of about 60,000, mostly from the Meto-speaking group that are dominant throughout western Timor (Figure 1, where Oecusse is the left hand red-shaded area). ${ }^{4}$ Oecusse has an intriguing political history: it is credited with the introduction of the Catholic Church to Timor in the early 1500s, was home to powerful kingdoms involving indigenous and part-European Topasses rulers who dominated trade through the $17^{\text {th }}$ and $18^{\text {th }}$ centuries (Boxer 1947, Oliveira 1949), and was the site of the first Portuguese capital on Timor until 1769. During the later period of Indonesian rule (1975-1999), the District's sandalwood stocks were devastated in the early stages of occupation (Meitzner Yoder 2007b:224-225), and later, settlements were destroyed by militias and troops following the 1999 referendum for Timorese independence from Indonesia (Meitzner Yoder 2005:20-

\footnotetext{
1 Dr. Laura Meitzner Yoder, Associate Professor, Sustainability and Environmental Education Department, Merry Lea Environmental Learning Center, Goshen College, Wolf Lake, IN 46796, USA. smyoder "at" goshen.edu. An earlier version of this article was presented at the International Conference on Revisiting agrarian transformations in Southeast Asia: empirical, theoretical, and applied perspectives, Chiang Mai, Thailand, May 2010. I thank Simon Batterbury and the reviewers for their insightful comments and assistance. I extend thanks to the Oecusse government and customary authorities, and to Michael Dove for helping to conceptualize the earliest draft. Research was funded by: a Yale University Doctoral Fellowship; Fulbright-Hays Doctoral Dissertation Research Abroad Fellowship; SSRC/ACLS International Dissertation Field Research Fellowship; Dissertation Research Grant, Yale Center for International and Area Studies; Mustard Seed Foundation Harvey Fellowship; Southeast Asian Studies Doctoral Fellowship at the RSPAS, The Australian National University; and Language Training Grant, Yale University Southeast Asia Program.

${ }^{2}$ While literature on Timor's famed beeswax is scant, there is a more extensive literature on the sandalwood trade (Bligh 1789, Burkill 1935:1954, Castro 1867:304, Cinatti Vaz Monteiro Gomes 1950:7, Duarte 1930:161-162, Groeneveldt 1960:116-117, Gunn 1999:52, McWilliam 2005, Meitzner Yoder 2007b, Ormeling 1956:95, Ptak 1983:37-40, Ptak 1987b:105, Reid 1995:100, Villiers 1985:59-64). See Meitzner Yoder (2005:54-76) for a summary of Timorese trade and sandalwood supply from A.D. 1200 onwards. McWilliam (2002:50-61) discusses the interplay of sandalwood control with colonial and indigenous politics in Dutch/Indonesian western Timor.

3 These motivations for forest conservation differ when compared with other regions where the discourses of ecological functions of forests are more commonly discussed among forest dwellers (e.g. Chusak 2008, Forsyth and Walker 2008, and Pinkaew 2001 for Thailand).

${ }^{4}$ Italicized terms throughout are from the Meto language (also known as Dawan or Baiqueno) unless otherwise noted.
} 
22). ${ }^{5}$ While Oecusse is of great historic importance to Timor Leste, the District is marginal to the modern Dilicentered state, separated by geography and poor communications. ${ }^{6}$ Its exceptionalism is now enshrined constitutionally; in independent Timor Leste, Oecusse-Ambeno is an autonomous region governed by special administrative and economic policies, although this unique status has yet to confer many practical benefits (Holthouse and Grenfell 2008, International Crisis Group 2010). Partly because of distance and inattention from central government, local customary authorities still possess substantial power at the local level. For example when Oecusse villagers discuss forest regulation today, two local kings who receive forest product tribute (usif in Meto or raja in Indonesian) and customary land and forest overseer-guardians who regulate resource use (the tobe) still figure prominently.
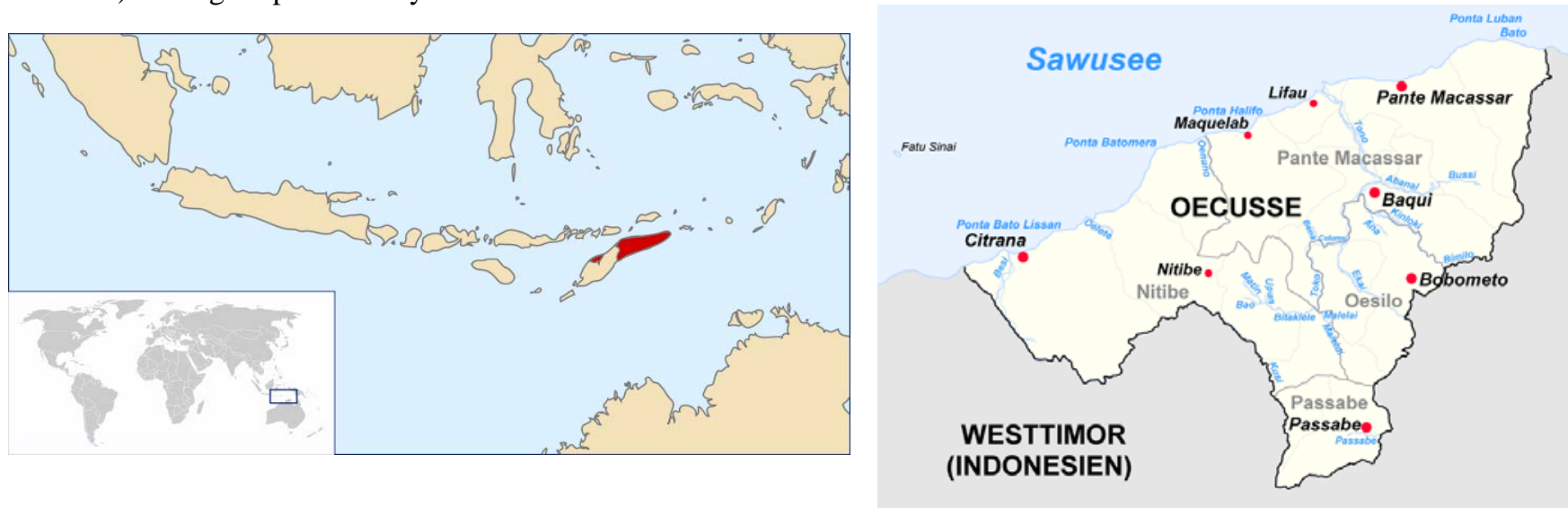

Fig. 1: Timor Leste (in red) in South East Asia, and Oecusse (left hand red area). Source: Wikimedia Commons.

Portugal was the minor colonial power in South-East Asia, and its territories were surrounded by Dutch possessions. The incongruous tenacity of the Portuguese presence through the $17^{\text {th }}$ and $18^{\text {th }}$ centuries, amidst the rise of the Dutch, has been attributed in part to their firm localization through intermarriage and use of religious symbols that came to play important roles in shaping a deep-rooted Catholic identity and affiliation (Hägerdal 2006, Newitt 2005, Roever 2002). This religious identity is still evident today. Hägerdal notes that "Dutch adversaries were often stunned by the power that Portuguese and Catholic symbols of authority possessed over the local Timorese aristocrats, given the rather superficial dissemination of Catholicism", and that the Portuguese were able to maintain their influence by transforming Timorese principalities through trade (2006:16). Religious

5 From the early sixteenth century, Portuguese presence in Oecusse consisted of seasonal trade and periodic visits from Dominicans who established a Church base on the nearby islands of Flores and Solor. A monument at the Lifau, Oecusse beach park states that "the Portuguese landed here on 15 August 1515," but historical texts are less certain about an exact arrival date of the Portuguese to Timor and to Lifau. The Dominican order established a base on Solor in the mid-1500s, and Flores later became a primary entrepôt for Portuguese traders in the region, serving as bases for the monsoon-determined trade (Boxer 1947:1, Villiers 1985). The Dominicans and traders operated on Timor for centuries with scant oversight from their political and religious authorities in Flores, Goa, or Macau (Villiers 1985). Priests were involved in sandalwood and beeswax trade alongside Church activities, and at various points became involved in civil rule of settlements as well (Villiers 1985). There are ample sources on this mercantile period in general Portuguese histories (Castro 1867, Leitão 1948, Oliveira 1949, Ptak 1987a); Sherlock noted that Portuguese historiography of this early period is more extensive than some later periods (Gunn 1999:17). The literatures on Asian trade at that time are vast, exploring linkages with China, within the archipelago, and with Indian Ocean and European trade destinations (Lach 1965, Lieberman 2003, Reid 1988, Reid 1993). While Church growth was slow, early allegiance from Lifau rulers was influential in making Oecusse an economic center and maintaining Portuguese linkages and influence (Villiers 1985). In 1641, the queen of Mena (just east of modern-day Oecusse) and the native Ambeno ruler were baptized into Catholicism (Castro 1867:27-28). Parada writes that the king, his family, and people were also baptized in Lifau (on 1 July 1641), naming the king as Francisco Ornai and his wife Agostinha (1974:560-61). For more on the Costa-Hornay/Ornai Topasses intrigues, see Boxer (1947).

6 This marginality is expressed in a multitude of ways: the extreme difficulties in transport and communication between Oecusse and the eastern body of Timor Leste, lack of familiarity with the Tetum language of the capital, the poorest performance nationwide on several human development indicators, and relative lack of state attention to the District.

7 There are about seventy tobe in Oecusse today, each responsible for a clearly bounded, named, nested territory within one administrative village headed by a naijuf, covering the entire expanse of the District. 
imperatives and symbols of authority conferred in the past by local kings, still have persistent power to control resource extraction.

Commentators have long linked sandalwood and beeswax exploitation to indigenous conflict and shifting borders in Timor. Leitão wrote that sandalwood interests caused many of the otherwise incomprehensible intrigues and conflicts (1948:173). Dutch geographer Ormeling noted that Timorese wax was used for Javanese batik in the early 1500s, with a significant trade continued by European companies into the late 1700s (1956:115); he continued, "The value of this product [beeswax] is evident from the fact that swarms of bees often caused violent border disputes in the past. Formerly worthless areas were suddenly quarreled about when the bees made their nests there. Borders frequently moved with the bees" (115-116). Writing from his experience as a Dutch administrator during the 1940s, Schulte Nordholt commented that boundary disputes for agricultural and pasture land were rare, but that "[f]riction is more likely to arise in issues concerning rights of disposal over sandalwood and the yields of 'bee trees'-besides cattle thieving, sandalwood and bees' wax are the most frequent causes of disputes and wars". These became increasingly serious if they crossed traditional authorities' boundaries (1971:225). Meto-speaking West Timorese still refer to sandalwood as hau lasi (tree of conflict or dispute) (McWilliam 2003), hau nitu (devil/spirit tree) and hau plenat (government tree) (Sa'u 2002:14-15). Castro (1950:160) and Felgas (1956:129) also mentioned conflicts arising over bee trees.

Colonial borders were also subject to resource-related disputes. Eastern Oecusse's formal colonial border remained contested once the rest of the zone had been demarcated by 1916, in part because both the Dutch and Portuguese sought to control this sandalwood-rich area (Durand 2002:51, Farram 1999:47-51). European disputes overlaid and reshaped, if not exacerbated, persistent indigenous land conflicts in this region that recur to this day. Although sandalwood was rarely mentioned in relation to the intermittent Dutch-Portuguese boundary negotiations that occurred throughout the nineteenth and early twentieth centuries, both sides' economic interests in this product were partially responsible for their protracted deliberations over demarcating their remote, problematic, and otherwise unprofitable colonies (Ormeling 1956:98-99). Conflicts over boundary demarcation between Timor Leste's Oecusse and Indonesian West Timor are ongoing (International Crisis Group 2010), and key figures in Timor Leste's political disturbances in 2006 were involved in illegal cross-border sandalwood smuggling (International Crisis Group 2006).

\section{Sandalwood's "discovery" and abundance in Oecusse}

In the early centuries of Asian and European trade, the abundance of Timor's sandalwood was legendary. Early Chinese visitors proclaimed that Timor's mountains were covered in sandalwood, and that the wood was so plentiful that the Timorese used it as firewood, a practice which made visitors ill from the smoke-a comment echoed by Europeans in the sixteenth and seventeenth centuries (Groeneveldt 1960:116, Ptak 1983:37, 40, Ptak 1987b:105, Reid 1995:100, Villiers 1985:64). ${ }^{8}$ Portuguese travelers noted the presence of Asian traders and local rulers who were already connected to the sandalwood and wax trade, and who followed ritual protocols surrounding wood harvest (Pigafetta 1969 [1522]:139). ${ }^{9,10}$

Oral histories I collected in Oecusse between July 2001 and November 2004 make clear mention of prePortuguese activity by Chinese traders in the region. Present-day narrators from eight Oecusse administrative villages (sucos, from the Portuguese) insisted that before the beginning of external trade, there were no local uses for the region's abundant sandalwood, and that Oecusse people did not know the purpose of this tree. ${ }^{11,12}$ In one

\footnotetext{
8 This varies from the current practice of burning small amounts of sandalwood to cure sick people, especially children, in enclosed spaces. In modern-day Oecusse, people also report burning sandalwood to repel mosquitoes and to scare away bad spirits (raising the question about what Timorese might have feared when they saw boatloads of arriving foreigners). Burkill (1935:1955-1956) lists further uses of sandalwood.

9 For centuries, Chinese traders were the only non-Timorese who travelled throughout Timor's interior (Fox 2000:18-19), even at significant personal risk (Ormeling 1956:132-135), and Portuguese travellers frequently mentioned the presence of Chinese residents in Oecusse (Oliveira 1950:282, 284, Teixeira 1974, Vaquinhas 1883).

10 This very early mention of rituals and restrictions on sandalwood harvesting supports some Oecusse people's assertion that the tree has long held special significance in Timor, and that special sandalwood protection pre-dated European dominance in Timor's sandalwood trade and influence on Oecusse's local authority structure. It is possible that sandalwood held some special local status before its entry into regional trade, and that brisk commerce in the wood reshaped the roles of Oecusse authorities.

11 Oecusse has between 18 and 26 administrative villages (Meitzner Yoder 2005:123-124); recognized village status and administrative divisions are a topic of great controversy in Oecusse.

12 McWilliam (2005:298) noted that West Timorese use inner bark of sandalwood as a betel (Areca sp.) substitute; in Oecusse, people chew a wide variety of bark and palm (rattan) seeds but do not mention using sandalwood. In Oecusse today, sandalwood is not traditionally used in any ornaments or implements for common people or for local authorities, other than rosaries. Two notable exceptions relate to kings' deaths: the Lifau grave of the Cruz-Ambeno lineage king (Carlos da Cruz) who died in 2001 is topped with a sandalwood cross, and there reportedly was a large sandalwood tree reserved to make the casket for Oecusse king José Hermenegildo da Costa, but the tree was inaccessible at the time of his death in October 1999 due to militia activity throughout Oecusse.
} 
common story, sandalwood's use became known and its value was revealed only when visiting Chinese traders came to Oecusse's shore with a sandalwood twig bearing leaves that they showed people, instructing them to cut and to bring this plant for trade to the coast. ${ }^{13}$ The Chinese eventually acquired sandalwood through a hierarchical chain of local leaders: the order for villagers to cut trees went from the king (usif) to the village heads (naijuf) to the ritual figures (tobe), with each of these customary authorities then receiving a specified length of wood with each harvest. A second version of sandalwood's "discovery" in Oecusse focuses on the aromatic quality of sandalwood roots and sandalwood's place in swidden fields. ${ }^{14}$ According to this story, a Chinese visitor smelled a fragrant knife handle being carved or accidentally singed by fire, asked to see its source, and was taken to the farmer's swidden field that had been invaded by roots from a neighboring sandalwood tree. ${ }^{15}$ The farmer indicated the spot and the roots he used to make his knife, and together they traced the root back to the sandalwood tree which was outside of the field's fence, highlighting sandalwood's link to cultivation.

Sandalwood trade Timor-wide was in serious decline by the 1800s, followed by another trade peak in the early 1900s. A center of intense trade for centuries, Oecusse was still known for its abundant stocks when other regions became depleted: on Timor, Oecusse alone had legal sandalwood harvesting and export after 1925; in 1950 Oecusse was named as the primary location for sandalwood in Portuguese Timor, associated with rotating swidden fields (Cinatti Vaz Monteiro Gomes 1950:17); and there were sufficient Oecusse stocks remaining in 1975 to permit a tenfold increase in regional trade from Oecusse in the early years of Indonesian rule (Meitzner Yoder 2005). ${ }^{16}$ While history books portray the resident kings and traders of Timor as responsible for the precipitous decline in sandalwood stocks, in Oecusse today the local authorities-including kings and tobe-are credited with an historic role in forest preservation through their parsimonious harvesting and strictly enforced regulations on sandalwood cutting through the end of the Portuguese colonial era.

\section{Beeswax in trade and as ritual tribute}

Timorese beeswax was an important item of regional commerce before the Portuguese presence, and it continued as an important trade item during the Portuguese era even after sandalwood's decline. ${ }^{17}$ Beeswax makes regular but minor appearances in the Portuguese literature, its scant mention seemingly out of proportion to its significant contribution to colonial income. Although local authorities in Oecusse imposed some restrictions on beeswax harvest and use, beeswax was even further removed from European or state purview than sandalwood. ${ }^{18}$ The colonial Portuguese government's relative lack of regulatory power over beeswax may have obscured their attention to its importance (cf. Dove 1986, 1996).

Raw wax was exported to Macau to be refined, and the Timor government made some payments in beeswax to Macau for its sporadic administration of Timor under Portuguese rule (Villiers 1985:69). Vaquinhas (1883:327) noted that "the kingdoms [Oecusse and Ambeno] produce in abundance much sandalwood and some wax which is exported, and in Sytrana [Citrana, western Oecusse] much rattan," a palm product which is

\footnotetext{
13 There is even a joke about how only two sucos managed to correctly identify the sandalwood tree that the traders desired, while other villages brought a similar tree known as papi in Meto, Exocarpus latifolia (McWilliam 2005:299). This story, as told with self-deprecating humor, revolves around Oecusse people's complete lack of knowledge about the tree such that it was not immediately evident to villagers what the first traders were seeking, although the tree was everywhere around them. It is also a commentary on the difference between what Oecusse people and the traders deemed rare, valuable, or interesting. Ironically, the papi tree (also semi-parasitic) was commonly used during Indonesian times in Oecusse as in West Timor "to bulk up supply by adding the pulp and heartwood of substitute tree wood from other species that have scented timber somewhat reminiscent of sandalwood" (McWilliam 2005:299), suggestive of similar mischievous response to the Chinese request.

14 One tobe narrator explained that sandalwood's purpose in trade was discovered early — at the time when there was only one village head (naijuf, in Passabe) and one king (usif, in Tulaica, the native Ambeno king); only after sandalwood's discovery did the Costa king come to Oecusse and the other naijuf were formed. This myth reflects the common statement that Oecusse's multiple kingship resulted from the sandalwood trade, collapsing centuries: Costa came as a trader (1500s), married the daughter of the Ambeno king (there were multiple such alliances over centuries), and became king of Oecusse (late 1800s or after the 1912 conflict).

15 The carver is often said to be an ancestor figure of the Ambeno royal lineage who features in a range of Oecusse myths, removing sandalwood from the domain of common people's use.

16 While Oecusse was still under Portuguese rule until 1975, Oecusse's primary Chinese sandalwood trader had to obtain all his wood from (Indonesian) West Timor due to the Costa king's extremely strict prohibition on cutting the wood within the District, then send it to Dili by ship. After Indonesian rule from 1975, his trade was entirely sourced from Oecusse, with a tenfold increase in quantity over previous amounts originating from the much larger region of West Timor.

${ }^{17}$ Colonial government figures do not differentiate the beeswax trade by region, so this discussion concerns the whole colony, not just Oecusse. However, Pigafetta's 1522 description refers to the significant wax trade out of Ambeno (Oecusse). Wax was sought after for batik production and high-quality candles.

18 The English naturalist Wallace (2000:153-154) provided a rare eyewitness description of wild beeswax and honey harvest on Timor [but not in Oecusse] from his 1861 visit.
} 
indicative of extensive, dense forest cover. ${ }^{19}$ Writing in the late 1860s Castro mentioned that sandalwood had recently gone from great commercial importance to insignificance; meanwhile, from 1858 to 1865, export charts indicate that beeswax provided 47-63\% of Portuguese Timor's customs export earnings. After this, coffee became more important, and the beeswax share dropped relative to coffee (Castro 1867:304 \& 340-354, Cinatti Vaz Monteiro Gomes 1950:13). Yet, in this important archival record the governor does not mention that beeswax supplied at least half the government's export earnings for eight years, and he focuses instead on increasing coffee production. Coffee came under direct control of colonial state agents through plantations and centralized processing - unlike wild-collected beeswax, which had decentralized production managed by individual Timorese tree owners. By the 1870s, both wax and sandalwood exports were dwarfed by coffee (Montalvão e Silva 1910:18). Yet, in 1916, a promoter of apiculture who lamented the unsustainable Timorese harvesting methods noted that Timor still exported 25,000 kilos (about 400 picos) annually (Panão 1916), at least the same quantities that had been exported in Governor Castro's time. ${ }^{20,21}$

Local kings have long had involvement in beeswax collection in western Timor, with some of the same exclusive rights to trade sandalwood applying also to beeswax as a tribute item (Foni 2002, McWilliam 2002:44, 144, Middelkoop 1960:128, Schulte Nordholt 1971). Middelkoop (1968:77) noted that disks of beeswax and balls of homespun cotton thread, the ninik-abas (wax-cotton) offering, were part of the kingly inheritance in Noi Muti, West Timor. In the middle of the twentieth century, these ritual beeswax tributes and local hierarchical relationships were still conducted across Oecusse's border into Indonesian West Timor without any barriers other than paying a small amount to border officials encountered on the way.

Although Timor's documented beeswax trade was active before Portuguese arrival, Oecusse oral narratives about the arrival of Dominicans to Oecusse link Catholic worship to beeswax collection. When highlanders narrate the origins of ninik-abas, the beeswax candle tribute items for the kings, the story goes that the Portuguese friars arrived to Oecusse's coast, and the newly converted (indigenous) Ambeno king sent word to the village head (naijuf) of Oecusse's southern highlands to bring beeswax and string to the coast for candles, to fulfill the ritual needs of Church worship. Another version relates how the Portuguese priests landed in Oecusse, and immediately sent a messenger to the naijuf, who went down to greet the Portuguese, and then commanded that beeswax candles be brought to the coast for use in religious ceremonies as required by the priests. From that point, beeswax collection was intimately tied to Church demands, and conducted through the customary hierarchy To this day most of the beeswax supplied to the Church is given first to the kings, who distribute a portion of the candles to chapels and churches. Although beeswax is no longer an Oecusse export, the Church-beeswax link persists in the pre-Easter beeswax tribute, described below.

\section{Formation and tasks of the tobe}

The origins and continued power of customary authorities in Oecusse are intimately tied to regulation of sandalwood and beeswax harvests. Sandalwood regulation and beeswax collection are two of the most prominent responsibilities of today's ritual land/forest authorities (tobe). Oral accounts describe how the king(s) instructed village political leaders (naijuf) and residents to appoint autochthonous individuals entrusted with responsibility for carrying out agricultural rituals (the tobe). The tobe should have location-specific communication with nature [fatu-haub, rock-tree] and the ancestors, which would be recognized through receiving symbols of authority, including a water-filled clay pot and beads, from the king. ${ }^{22,23}$ The tobe were to take food to both kings to ensure

\footnotetext{
19 The Costas frequently carried out their contraband trade in Citrana (Dores 1901:818). Citrana is still the site of the Costa king's primary coastal wax- and betel-producing forest. Costa was said to have introduced sacks of betel seed to Oecusse from a neighboring island, and all the Oecusse villages came together to plant the extensive communal betel forest, which remains to this day in a zone of intense border dispute with Indonesia (International Crisis Group 2010, Meitzner Yoder 2005:241-248).

201 pico=60.5 kg (Leitão 1948:175, n.5). Governor Castro noted that the price of one pico of wax in 1862 averaged 100 rupias (1867:347). Another unit used for beeswax is the cate: 1 pico=100 cates=133 arrateis (Castro 1867:340). Thomaz (1974:268) attributes the $62 \mathrm{~kg}$ pico to Malay origins (pikul) and the 620 gm cate to Malay kati, noting that both measures fell into disuse with the rise of the metric system.

21 Beeswax remained an important Timorese export trade item to the twentieth century. The 1882 listing from a Portuguese museum collection noted that there was significant beeswax production in Timor, and that export was primarily to Dutch areas for cloth production, valued at eighty rupias per pico (1882:70); sandalwood was listed as also abundant on Timor but with no local uses, and was valued between five and fifteen rupias per pico (74). Vaquinhas, who helped assemble the museum items from Timor (1882), listed wax among Oecusse's exports (1883:327). Exports from 1919 to 1925 show a rapid decline in sandalwood alongside a more sustained supply of beeswax during this period, with greater total income from wax than from sandalwood during this period. (P.:148). Felgas noted that before the Second World War, Timor normally exported 35-45 tons of wax, and that in 1952, wax exports added up to 16 tons (1956:129).

22 For narratives on the origins and progressive divisions among usif and naijuf, see Meitzner Yoder 2005.

23 The tobe have agricultural ceremonial roles similar to those found throughout Timor (Foni 2002, Friedberg 1989, Hicks 1990, McWilliam 2002, Neonbasu 1992a, Schulte Nordholt 1971, Traube 1986). Friedberg (1989) wrote of customary figures with oversight of sandalwood and beeswax among the Bunaq.
} 
future agricultural productivity. ${ }^{24}$ As additional tasks of the naijuf and tobe accumulated, additional tobe were added to each domain. As narrated to me by contemporary tobe and naijuf in Oecusse's highlands:

After da Costa was also made king, there was religion. So a new task given to the tobe and naijuf was that of ninik-abas, since the people already had religion and Senhor Morto had already arrived to Ambeno. ${ }^{25}$ So every year the tobe and naijuf take beeswax and cotton wick to the palace to use in church.

After the arrival of da Costa and trade was bringing things in and out, then the people knew the purpose of sandalwood, which was plentiful on Timor. Da Costa went and told the Chinese to come and get sandalwood from Timor, but it had to be taken with the correct rituals. ${ }^{26}$ Because after da Costa knew this product, he called all the tobe and gave them power to protect the existing sandalwood trees by giving each tobe a chisel [paha]. ${ }^{27,28}$ So when the king requested sandalwood, then the tobe himself would perform a ritual in his sacred house, then go out with the people to find sandalwood. The tobe would arrive to the trees first and check them with the chisel to determine whether they already had enough aromatic heartwood to be cut or not. The king also warned people that anyone who stole sandalwood would face severe consequences. ${ }^{29}$ The same was true for beeswax; it could only be harvested with permission of the tobe, and after the tobe performed a ritual. ${ }^{30}$

This oral account describes the genesis of forest product control, under the direction of local authorities who used threats of temporal and supernatural consequences to restrict unregulated harvesting. The tobeindividuals with pre-existing ritual authority in the realm of supernatural communication concerning agriculturewere selected by local residents and charged with performing agricultural rituals. They were given added responsibility and recognition by the king(s) for their exclusive access to the two most valuable commodities of the region. Ensuing regulation of wood and wax by the tobe served to bolster the position of the kings, whose influence and power increased as a result of their trade monopoly. Widespread recognition of this special authority over sandalwood and beeswax harvest persists to this day, although transgressions are common

24 Both kings - the indigenous Ambeno lineage known as da Cruz and the in-married part-Portuguese trader lineage known as da Costa-have residential palaces (sonaf), which are indistinguishable architecturally from other regional residences.

25 This life-sized image of the dead Christ used in the Good Friday service, said to be brought from Portugal via other nearby islands, is still under the care and guardianship of the Costa royal family today.

26 This is reminiscent of the oft-stated belief in Oecusse that sandalwood cut without proper ritual will not contain aromatic heartwood, even if the tree is large and should have ample development. In contrast to Pigafetta's detailed 1522 description of rituals and lunar timing surrounding sandalwood harvest, at present in Oecusse, there seems to be no ideal lunar time for sandalwood harvest.

27 The relative involvement of the Costa and Ambeno/Cruz kings in sandalwood is complex. While all stories indicate that there were no local uses of the tree before traders made Oecusse people aware of its value, some insist that the wood has always been a sacred symbol and protected by the native kings. Others, as here, clearly indicate that the Costa king originally gave the tobe a chisel (used to check for adequate presence of the valuable aromatic heartwood in a given tree before cutting) to regulate access to the wood, thus protecting his own trade monopoly, as primary sandalwood merchant in the region. When I asked tobe who gave them their chisels, they replied that it was Costa or both Costa and Ambeno kings. Members of the Ambeno king's lineage state that the Ambeno king conferred the chisels. When asked about this variability, one tobe responded that it was the Costa king who actually conferred the chisel, but with the permission and knowledge of the Ambeno king.

28 Tobe possess objects that evidence their authority, including small woven palm-leaf baskets (from which they derive their name) used to hold rice thrown on ancestral shrines and other sacred objects during ceremonies, weavings used to hold rice, and bead necklaces. Among those tobe with authority over sandalwood, the most important symbol and tool of power is the chisel. People insist that only wood that the tobe approved in the proper manner could yield the desired product; wood taken without observing the requisite rituals and authorities would not yield heartwood, even in a very old, large tree. And so the tobe's ritual power became tied to efficacy in wood harvesting. The metal chisel, as a trade item imported to Timor, also bears linkages to the outside-including its conferral by the non-native Costa king.

${ }^{29}$ In recent reinstatement of tobe power over land and forests, unregulated sandalwood harvest often incurred a penalty many times higher than any other infraction (Meitzner Yoder 2007b). During the late Portuguese period, people who cut sandalwood without permission in Oecusse were said to be at risk of exile by the Costa king to the island of Atauro, off Timor's northern coast near Dili.

30 Non-Church rituals surrounding beeswax production and harvest remain strong in Oecusse, although by all accounts the amount of wax produced now is far less than it used to be. Those individuals charged with collecting Easter wax spend much time lamenting its high cost and current scarcity. Pre-harvest ceremonies for wax and honey, said to be unique among ceremonies throughout Oecusse for requiring the sacrifice of a horse, are intended to induce the bees to come back to that same place every year (cf. Tsing 2003). Nowadays, with the scarcity of horses, a goat or other small animal is used. It is also possible that the requisite (high-value) horse is symbolic, but always negotiable and normally substituted for a lesser animal (cf. Fox 2002). Today, beeswax pre-harvest rituals, including sacrificing an animal at the base of the honeycomb-holding tree, can be (and are) performed by the tree's owner rather than the tobe. 
(Meitzner Yoder 2007a, 2007b). Both sandalwood and beeswax were subject to similar regulation by local authorities: a tobe had to conduct preliminary rituals and oversee the harvests, and a portion of each always went to the king.

Narratives place sandalwood in the political-economic domain, and beeswax in the religious-ritual domain. Stories describe the collection and use of beeswax candles, overseen by the tobe, as a novel task dating to the arrival of the Catholic priests to Oecusse's shores. Candles are currently used in traditional (animist) ceremonies in the same way they are used in Church rituals, but Oecusse people contend that beeswax collection was not done previously for the Ambeno king or for trade before Costa's arrival. Outsiders and introduced goods play important roles in Timorese stories of origin and social change (Fox 1992, Fox 1995, Traube 1986); the arrival of Costa to Oecusse-Ambeno is widely associated with bringing not only religion and increased trade to the region, but also firemaking (so food could be cooked, not just eaten raw), education, coins, betel palm, and other markers of civilization (Meitzner Yoder 2005). Some narrators mentioned that bringing beeswax tribute symbolized acceptance of Costa as (a) king, and is also symbolic of bringing a local product back to the king who brought so many valuable outside items to Timor. Similarly, the above story indicated that in giving a chisel to the tobe, the tool and symbol of their sandalwood authority, the Costa 'king' added this element to their other ritual tasks, that concern land, forests and agriculture. With the arrival of traders from Asia and Europe, sandalwood went from an abundant, unused species to become a primary target of overseas visitors to the island, and rapidly depleted. Was it this abrupt change in importance and value that prompted the Oecusse king to create for the tobe the special, exclusive role in overseeing and controlling sandalwood harvest? Did the tobe have any protective role over sandalwood before the arrival of the traders? In the days when sandalwood was abundant, unused, and unrecognized, was anyone responsible for protecting it, or were tobe only assigned this role when sandalwood became a scarce, sought-after commodity?

When I discussed this idea individually with several contemporary Oecusse political leaders who are also recognized as customary authorities, they rejected my interpretation. They insisted that in principle, tobe have always protected sandalwood since the beginning of time, and that the earliest kings placed prohibitions on the aromatic wood for spiritual reasons alone. In their view, it was this innate protection that led to sandalwood's abundance and lack of local uses in the first place, rather than my suggestion that their protective role arose in response to a king's desire to control sandalwood harvest. From the earliest of times, active local authorities were responsible for shaping and fostering Oecusse's forests, attributing a high degree of human agency to sandalwood's growth on Timor. These leaders were unwilling to portray the tobe roles as merely responsive to the imperatives of external trade. A changeless model of traditional authorities' past responsibilities bolstered the legitimacy of their interest in restoring power to local customary authorities (Meitzner Yoder 2007a, 2007b). They explained that the Costa king's conferral of chisels to the tobe merely lent official recognition to their existing roles, rather than initiating new tobe responsibilities.

\section{Contemporary practice and importance of beeswax tribute}

While many Oecusse people, and the royal families themselves, sometimes mention that there is no place for local royalty in a modern democracy, the persistence of tribute is an indicator of a popular recognition of kingship. It also testifies to the endurance of local authority structures embedded within a pervasive Catholic identity, illustrating the close relationship between the traditional hierarchy of usif-naijuf-tobe and the Catholic Church. Nearly all villages still bring annual harvest tributes to the king(s) in recognition of this position as the ultimate landowner(s) for all of Oecusse-Ambeno. People's participation in this event provides a rare concrete opportunity to discern forms and realms of responsibility within the customary authority structure across the District. The pre-Easter beeswax candle tribute of ninik-abas and pentauf/penasu (dried ears of maize still on the stalk, usually tied in bundles of eight) is intended to ensure social harmony within the kingdom and good harvests for the coming year. ${ }^{31}$ In contrast to the decline in many aspects of kingdom life after the end of Portuguese rule in 1975, this practice continued uninterrupted throughout the Indonesian era and until today.

Beeswax is now a relatively scarce commodity in Oecusse, and tobe save up wax as they find it throughout the year for the Easter tribute. The wax has several colors ranging from white and yellow to pink and dark brown, said to depend on the type of tree flowers the bees visited. The matter of obtaining wax is the main topic of discussion at the events involving candles. The few villages with extensive forests-including Ben-Uf, Lel-Uf, Cutet, and Malelat-have abundant wax, which is harvested around June and stored for the following year. Certain forests are under special protection by the kings specifically to ensure wax production, and these forests are a source of great village pride. An extensive forest on Oecusse's southwestern border (in Suco Lele-Uf) has been protected by tobe since the king(s) designated that forest specifically as Oecusse's primary beeswax production forest-including strict restrictions on entry to the forest even by village residents. Anyone entering the forest must first add a stick to a large pile near the path on the way in (which monitors the number of visitors), and no one is allowed to remove anything from the forest without permission, including dead wood, fallen fruits,

\footnotetext{
31 While most villages use the terms penasu and pentauf interchangeably, some villages distinguished penasu as the maize tribute taken to the naijuf, while the pentauf was taken to the king.
} 
or dried leaves. In striking contrast to the bare, dry land surrounding all the nearby settlements that suffer water scarcity, the forest is humid enough to host abundant mosquitoes. For all forests under similar royal decree, their continued existence is inseparable from oversight by customary authorities. Villagers in Ben-Uf were relocated to coastal settlements during the Indonesian period, making monitoring of their interior, highland beeswax forest more difficult. Tobe or the Costa king's assistants (ajantis, from Portuguese) from the other villages make lastminute collecting expeditions to source villages or purchase wax in the markets, which is considered expensive; in 2003, a wax disk of $8 \mathrm{~cm}$ diameter and $3 \mathrm{~cm}$ height cost more than US\$2.50, in a cash-scarce society.

In the weeks preceding Easter, coinciding with the main swidden food crop harvest time, tobe and ajantis oversee the village-level collection of wax and thread, coconut oil, betel, and maize. Each household must provide a small amount of these items, or contribute money (usually 5-10 US cents) toward their purchase. Village delegations of tobe, naijuf, ajanti, or village elders take these items to the two kings' coastal residential palaces (to Oe-Sono for the Costa king, and/or to Tulaica for the Ambeno king) during the week before Easter, for the Church and for personal use by the kings.

The wax and cotton thread (wick) are used to make Easter candles, and the coconut oil is used in half-shell coconut lamps placed around the churches. The betel is shared with those who monitor and replace the candles burned overnight after the Good Friday services. Harking back to four centuries of Topasses history which chronicles the power struggles of Costa and Hornay (Boxer 1947), three (not two) kings receive recognition in the um-uma bamboo poles on which candles are burned throughout the night. These are placed in front of the beachfacing Church, the Costa um-uma is maintained by the Costa king's ajantis; behind the Church, two poles represent the current Ambeno king (west side) and the Hornay king (east side), and their candles are maintained by two groups of elders from the eight closest villages. ${ }^{32}$ Extra cotton thread is used to weave the cloth that both women and men usually wear, and the maize is placed in the palace for consumption or distribution by the royal family. The amount of maize varies from village to village and year to year, depending on the quantity of harvest; some villages bring one ear from each family, and others bring one bundle of maize for each local leader who goes to the palace.

The beeswax candles are central to this event, and there are historical assignments for each village to take ninik-abas to one or both palaces. ${ }^{33}$ Historic division of villages and political affiliations with the kings are reflected in the beeswax offerings. While the eight villages of northeastern Oecusse go primarily to the Oe-Sono (Costa) palace, some other villages contribute wax to Oe-Sono via the two villages with closest affinity to the Costa kingship. ${ }^{34}$ Although not all villages had local leaders attend the Oe-Sono ceremony for delivering, counting, and submitting the candles to the old Oecusse Church where Good Friday activities are centered, all villages are said to be represented in this event. ${ }^{35}$ There are villages that take ninik-abas primarily to Tulaica, and several villages take ninik-abas to both Tulaica and Oe-Sono, usually assigning customary leaders from different regions, divided along the named tobe domains of authority, to one palace or the other. ${ }^{36}$ Naimeco village is unique, taking already-made candles to both kings, given to both of them on Good Friday at the Church, rather than materials delivered in raw form to the palaces ahead of time. At the Church during the Good Friday service, a naijuf of each (of eighteen) villages also receives one candle made from the Tulaica palace, whether they had contributed wax to Tulaica or not. A few distant villages, Ben-Uf for example, also take candles directly to their local chapels.

Any village that neglects its responsibility receives a fine that must be paid on the spot or within the following year; three different villages paid fines of cash and animals in 2003 and 2004 for failing to bring wax of adequate quantity or quality. Villages that take ninik-abas to Oe-Sono can bring rounds of beeswax to the palace

32 The villages are: Taiboco, Lifau, Bobocasse, Tunbab [=Sacato/Nipani], Cutet [=Costa], Naimeco, Cunha, and Lalisuk, headed by Bobocasse and Naimeco, respectively.

33 Despite other contenders for the Costa kingship, in 2003 and 2004 tribute taken to the Oe-Sono palace was received by Antonio Hermenegildo da Costa. Marcarius da Cruz received tribute taken to the Tulaica palace.

34 The villages are: Costa, Kutet, Nipani, Cunha, Lalisuk, Lifau, Naimeco, and Bobocasse. Cunha and Lalisuk are distinctive from all other Oecusse villages in being formalized relatively late, with lowland agricultural activities centered on flooded rice rather than dryland swidden farming, and a matrilineal inheritance system. One narrator mentioned that Naimeco, Bobocasse, Kutet, Nipani, Cunha, and Lalisuk always take tribute to the Costa king, and the other villages take them to the Tulaica (Ambeno) king. Usitaqueno, Lifau, and Lele-Uf/Hao-Uf villages also reportedly take tribute to Costa at Oe-sono. I compiled these listings of which villages take ninik-abas to which palace partly from personal observation and partly from oral accounts, which varied a bit from speaker to speaker. Asking a group of tobe in a given village about their practices did not always yield a clear answer to this distribution. The latter two communties, Cunha and Lalisuk are distinctive from all other Oecusse villages in being formalized relatively late, with lowland agricultural activities centered on flooded rice rather than dryland swidden farming, and a matrilineal inheritance system.

35 This ceremony is held in the afternoon of the Wednesday before Easter.

36 Usitasae, Bobometo, Banafi, and Ben-Uf go primarily to Tulaica. Malelat (usually earlier than the other sucos), Lifau, Usitaco (and its Poas-Bot enclave), Bobocasse, Taiboco, Suni-Uf, and Abani-Passab go to both. 
the week before Easter, which is then made into candles at the palace by the Costa king's assistants. ${ }^{37}$ Most $^{3}$ villages' tobe or ajantis, however, make the candles in the village and bring them to the ceremony before Easter, in 2003 and 2004 collecting more than several hundred candles, which were carried to the Church for presentation to the Oecusse priest. The Tulaica palace receives primarily rounds of wax and string, and men who live nearby spend several days making the candles at the palace.

\section{Political ecologies of wood and wax: differences in disturbance, tenure, and regulation}

I have illustrated how sandalwood and beeswax played important roles in the formation of Oecusse's economy, politics, and social obligations. Prior to and during the colonial period, traders obtained both these inland forest products at the coast, through dealing with local customary authorities - a transaction that strengthened the power of these intermediaries and may have motivated them to impose the harvesting controls on sandalwood and beeswax that are still evident in Oecusse today. But the different ecologies of each product led to different localized tenurial regimes. These influenced the forms of control that customary authorities could impose on them. These 'political ecologies of wood and wax', therefore, had environmental and social origins.

Sandalwood (Santalum sp., dominated by Santalum album in Timor) is a root-parasitic tree that thrives in ecologically diverse regions throughout the Asia-Pacific region, ranging from Hawaii to India (1990, Burkill 1935:1952, Watt 1908:976). ${ }^{38}$ Sandalwood thrives on poor, dry soils, often in stony and alkaline conditions in Timor (1990:2). All species are fire-sensitive (1990:2), an important factor in the tree's association with swidden fields in Oecusse. The tree is prized for its extremely valuable oil, and Santalum album yields the highest quality oil of all species (6-7\%), although the oil-producing heartwood content varies significantly among trees and stands for reasons not yet well understood by science (1990:4). Water stress and slowed growth contribute to higher oil yields, and genetic variation (within species and regarding the age of heartwood development) plays an important part in oil production for an individual tree (1990:4); early observations noted that poor soils improve the quantity or quality of the oil in the heartwood (Watt 1908:976) or even oil content of the roots (Burkill 1935:1956). The broad range of ecological and genetic variability affecting heartwood production for a given tree is reflected in the individual tree selection for harvest by the tobe in Oecusse, with the use of his chisel.

Sandalwood prevalence is closely linked to cultivation. ${ }^{39}$ Oecusse farmers often know that sandalwood occurs most abundantly in abandoned swidden gardens; it is frequently found in disturbed habitats, like pathsides, land subjected to road-building, and edges of new agricultural terraces. Deliberate planting from seed of this semi-parasite is challenging (although the focus of propagation efforts, 1990), but propagation by cutting the roots is quite effective. Birds are also credited with sandalwood seed dispersal in swiddens as they feed on the tree's fleshy fruits (1990:8). Oecusse farmers tell how they sometimes find a distant field, last used for swidden farming ten to twenty years ago, thick with sandalwood trees every meter or so-a circumstance that brings them dismay, given the local restrictions imposed on cutting the trees when they plan to use the land for agriculture. Encountering such a field is said to require one of three actions: leaving it alone for the sandalwood to mature for thirty to forty years; quickly cutting all the trees and disposing of them before the village tobe discovers their existence and enforces their protection; or, if the sandalwood's presence is already known to the tobe and the trees are not too close together, the laborious work of carefully clearing the brush and ground around each sandalwood tree, and wrapping each one in banana stalks to protect the tree from fire damage before burning the garden in preparation for planting. The trees are commonly found privately cultivated plots. Where sandalwood does occur in sacred or protected forests, farmers say that its existence there proves that those areas must have been cultivated gardens in former times. As noted above, access to sandalwood anywhere in Oecusse is controlled by the local tobe, under the authority of the customary village head (naijuf) who answers to the king (usif). Individuals with sandalwood on their property rarely view the trees positively, or as a source of profit (McWilliam 2005).

While sandalwood is known to appear in fields as a result of human activity, wax-yielding beehives naturally occur in older trees, in relatively undisturbed forest. Beeswax production requires large trees, which are now rare outside the protected forests. Certain trees are said to house bees year after year, and they rebuild their hives after a honey and wax harvest, but locals fear disturbing them too much (by gesturing or loud speech near their hives) since they risk stinging or causing the bees to relocate. Thus, there is some limited human agency (or

\footnotetext{
37 There are three sizes of candles used on Good Friday: the king's candle, one meter long, held by a selected ajanti from Cunha-Lalisuk; candles used inside the Church, 30-40 cm; and the ajantis' and elders' candles, $15-20 \mathrm{~cm}$, which they tie to the raised poles (um uma) around the Church and change throughout the night. To make the candles, melted wax is poured over wicks suspended from a notched palm rib until the candles reach the proper size. The candles are then cooled in water, rolled along a board to smooth the surface, and trimmed so they have a flat base.

38 Although reports of the species' parasitic nature and broad range of host plants were published in 1871 (Watt 1908:976), it took decades for those involved in its propagation to learn of this trait (Burkill 1935:1953). For Portuguese Timor, Cinatti discovered the root parasitism when investigating a failed 1946 sandalwood cultivation project (1950:16-17).

39 Ormeling (1956:173-174) and McWilliam (2005) comment on the close association of sandalwood and fallowed swidden fields.
} 
an absence of agency) involved in the continuing presence of the bees. ${ }^{40}$ Bee trees are nearly always subject to individual ownership across Timor (Metzner 1977), but these large trees are often found on commons land, including protected or sacred forests. The products from an overnight beehive harvest include honey (often completely consumed on the spot, and shared freely among those present), bee larvae (made into a spicy side dish), and wax (scarce enough now to reserve most of it for Good Friday use). Supply monitoring comes from the tobe and king's assistants (ajantis), aimed at ensuring adequate supplies for Good Friday. Individuals discovering beehives in their trees, or claiming a tree where bees have begun to settle, can decide how the hives will be harvested without regulation by the tobe, and owners may profit from this. ${ }^{41}$

Oecusse villagers and government officials share starkly contrasting symbolic associations of sandalwood and beeswax. Mentioning sandalwood prompts stories of regulation and fear of discovery, covert behavior, and punishment for infractions of customary law, or for refusal to provide the wood demanded for export in the early days of Indonesian rule. Sandalwood was a product long regulated by a local hierarchy that essentially maintained a trade monopoly, with cutting permissible only by order of the king. Nevertheless, the late 1970s militaryassisted decimation of Oecusse's renowned sandalwood stocks that had long been protected (or at least controlled) by local customary authorities is deeply resented. This loss of local control over sandalwood harvest is said to represent a profound disregard for Oecusse's customary leadership, supplanted under Indonesian rule. As this transition was inextricably linked to environmental degradation, the narrative of forest restoration includes restoring traditional authorities' control of sandalwood access, or at least expanding conservation activities beyond the exclusive domain of the state (Meitzner Yoder 2007b, Palmer and Carvalho 2008). Tales of sandalwood are stories about the vagaries of economic interest and external political regimes. By contrast, beeswax forests and tributes were shielded from interference under Indonesian rule by virtue of being linked to Church ritual. Continued ninik-abas offerings, in which all Oecusse residents participate through diffuse, decentralized wax production and donations, epitomize the positive associations of customary authority, ritual, and forest protection. Maintaining dedicated forests and large trees for beeswax production is a culturally powerful act that illustrates the persistence of resource regulation intertwined with customary and religious identity. Figure 2 (on next page) summarizes the contrasting ecological and tenure associations of these products.

\section{Conclusion: enduring political and ecological impacts of wood and wax regulation}

Beeswax and sandalwood no longer hold the significant economic role they did in Timor's past, but they are still imbued with political and ritual significance acquired in an earlier era. Hägerdal (2006) asked why there was a tenacious historic Timorese allegiance to the Catholic-Portuguese project. The persistence of beeswax tribute and customary sandalwood access demonstrates how enduring these symbols of authority have been, especially when firmly embedded within a pervasive religious identity and local political hierarchy.

Tales of wood and wax provide a unique window into the customary political history and current structure of Oecusse-Ambeno. Narrated stories of sandalwood's "discovery," and the genesis of beeswax candle tribute, both contain the transformative elements of foreign influence common in Timorese accounts of social change: outsiders' arrival carrying new knowledge and uses for local resources, religious conversion of the indigenous king, the recognition of the Costa kingship, and the tobe's new sandalwood and beeswax tasks. Local ignorance concerning sandalwood and beeswax was said to be supplanted by foreign knowledge, and the customary mechanisms put in place to regulate the wood and wax harvests persist to this day. Outsiders involved the hierarchy of local authorities in resource acquisition, and those local structures evolved in response to novel resource demands. To this day, we get a glimpse of centuries-old Topasses history in the candles burned at the Good Friday service. Both the arrangements for the kings' receiving and use of beeswax tribute for the central Church event, and the subsequent re-distribution of candles by the king to each village head, reinforce the strength of these long-established symbols of exogenous-induced change.

Customary figures' abilities and their recognized (if now diminished) authority to regulate access and harvest of forest products was at the core of newly independent Timorese government's efforts to "reinstate" the tobe and to officially re-invest them with the power to regulate resource use (Meitzner Yoder 2007b). Local authorities, whose positions and roles were established and strengthened through centuries of control over valuable trade resources, are now in a position to apply this control in new ways.

40 Tsing (2003) described songs used to calm bees and to entice them to remain and to return in Kalimantan, portraying a much greater role for human action in relationship to this "wild" resource. I have not yet investigated such songs or bee-luring actions in Oecusse.

41 Individuals who happen upon a hive-containing tree mark their claim to future harvesting rights by tying a leaf to the trunk of the tree. Only residents of the village (suco) containing the bee tree can lay claim to the harvesting rights. 


\begin{tabular}{|c|c|c|}
\hline & Sandalwood & Beeswax \\
\hline Occurrence and incidence & $\begin{array}{l}\text { Cultivated areas, disturbed soil } \\
\text { zones that cut roots, birds drop } \\
\text { seeds }\end{array}$ & $\begin{array}{l}\text { Undisturbed forests, on large } \\
\text { trees with strong branches }\end{array}$ \\
\hline Disturbance & Encourages propagation & Causes bees to leave \\
\hline Ownership & $\begin{array}{l}\text { Linked to land where found: } \\
\text { held in common (in sacred } \\
\text { forests), by a king, or by } \\
\text { individuals-but everywhere } \\
\text { subject to regulation }\end{array}$ & $\begin{array}{l}\text { Linked to tree where found: } \\
\text { belongs to the individual who } \\
\text { discovers and claims the tree } \\
\text { containing the hive }\end{array}$ \\
\hline $\begin{array}{l}\text { Villagers' current impression of } \\
\text { abundance }\end{array}$ & Less than before & Less than before \\
\hline Reasons given for decline & $\begin{array}{l}\text { Rapid, forcible wood extraction } \\
\text { by parastatal-military agencies } \\
\text { in late } 1970 \text { s }\end{array}$ & $\begin{array}{l}\text { Progressive loss of large trees } \\
\text { as villagers clear land for } \\
\text { themselves }\end{array}$ \\
\hline $\begin{array}{l}\text { Symbolic associations during } \\
\text { Indonesian era (1975-99) }\end{array}$ & $\begin{array}{l}\text { Abuse of military power in } \\
\text { forcible tree harvest, } \\
\text { displacement of and disregard } \\
\text { for local authorities charged } \\
\text { with sandalwood oversight in } \\
\text { the customary hierarchy, and } \\
\text { impermanence of political } \\
\text { regimes }\end{array}$ & $\begin{array}{l}\text { Comforting continuity in } \\
\text { religious-ritual activities, } \\
\text { source of enduring strength in } \\
\text { difficult and changing times; } \\
\text { beeswax tributes continued } \\
\text { unabated even after customary } \\
\text { authority structure was } \\
\text { dismissed regarding } \\
\text { sandalwood }\end{array}$ \\
\hline Discovery meets with... & $\begin{array}{l}\text { Dismay over limitations on } \\
\text { cultivating the land }\end{array}$ & Excitement of a new claim \\
\hline Individual profit & $\begin{array}{l}\text { None; or shared with multiple } \\
\text { customary authorities }\end{array}$ & $\begin{array}{l}\text { Highly valuable to tree } \\
\text { owner/claimant }\end{array}$ \\
\hline Land tenure & $\begin{array}{l}\text { Private on agricultural land, or } \\
\text { less commonly on } \\
\text { public/commons land }\end{array}$ & $\begin{array}{l}\text { Public/commons of dense } \\
\text { forests, or less commonly } \\
\text { private land }\end{array}$ \\
\hline Tree tenure & King, village, individual & Individual \\
\hline Key authority for regulation & Tobe & Tree owner/claimant \\
\hline Harvest initiative & King and tobe & Tree owner/claimant \\
\hline Product recipients & King, naijuf, tobe, individual & $\begin{array}{l}\text { Owner/claimant, harvester, } \\
\text { anyone who attends (honey, } \\
\text { larvae), Church (wax) }\end{array}$ \\
\hline Product use & Trade/external sale & $\begin{array}{l}\text { Consumption, Good Friday } \\
\text { candles, sale }\end{array}$ \\
\hline Associated realms & Political-economic & Religious-ritual-culinary \\
\hline
\end{tabular}

Fig. 2: Sandalwood and beeswax associations in Oecusse. Source: Oral histories, 2001-4.

\section{References}

1882. Governo da Provincia de Macau e Timor. Boletim da Provincia de Macau e Timor XXVIII: 66-77.

1990. Sandalwood in the Pacific: a state-of-knowledge synthesis and summary from the April 1990 Symposium. In Symposium on sandalwood in the Pacific, April 9-11, 1990, Honolulu, Hawaii, pp. 1-11.

Bligh, W. 1789. A voyage to the South Sea for the purpose of conveying the bread-fruit tree to the West Indies, including an account of the mutiny on board the ship. London: George Nichol. (online at http://www.gutenberg.org/ebooks/15411)

Boxer, C. R. 1947. The Topasses of Timor. Institut voor de Tropen. Afdeling Culturelz en Physische Anthropologie. n.p.: Koninklijke Vereeniging Indisch Institut Mededeling no. LXXIII No. 24.

Burkill, I. H. 1935. A dictionary of the economic products of the Malay Peninsula. Vol. II (I-Z). London: Crown Agents for the Colonies.

Castro, A. d. 1867. As possessões Portuguezas na Oceania. Lisboa: Imprensa Nacional.

Castro, G. P. P. 1950. As minhas memórias. Vol. Terceiro. Lisboa: Edições Expansão. 
Chusak Wittayapak. 2008. History and geography of identifications related to resource conflicts and ethnic violence in Northern Thailand. Asia Pacific Viewpoint 49 (1):111-127.

Cinatti Vaz Monteiro Gomes, R. 1950. Esboço Histórico do Sândalo no Timor Português. Lisboa: Ministério das Colónias, Junta de Investigaçoes Coloniais.

Dove, M.R. 1986. The practical reason of weeds in Indonesia: peasant vs. state views of Imperata and Chromolaena. Human Ecology 14: 163-190.

— 1996. Rice-eating rubber and people-eating governments: peasant versus state critiques of rubber development in colonial Borneo. Ethnohistory 43: 33-63.

Duarte, T. 1930. Timor (Ante-camara do Inferno!?). n.p.: Famalicão.

Durand, F. 2002. Timor Lorosa'e, pays au carrefour de l'Asie et du Pacifique: Un atlas géo-historique. Marne-laVallée: Presses Universitaires de Marne-la-Vallée.

Farram, S. 1999. The two Timors: the partitioning of Timor by the Portuguese and the Dutch. Studies in Languages and Cultures of East Timor 2: 38-54.

Felgas, H. A. E. 1956. Timor Português. Lisboa: Agência Geral das Colónias.

Foni, W. 2002. Budaya pertanian atoni pah meto: suatu studi siklus ritus kegiatan pertanian lahan kering atoni pah meto tunbaba di Timor Tengah Utara, Nusa Tenggara Timur. Program Pascasarjana, Universitas Kristen Satya Wacana.

Forsyth, T. and Walker, A. 2008. Forest guardians, forest destroyers: the politics of environmental knowledge in Northern Thailand. Seattle: University of Washington Press.

Fox, J. J. 1992. The heritage of traditional agriculture in Eastern Indonesia: lexical evidence and the indications of rituals from the Outer Arc of the Lesser Sundas. In J. Fox (ed.) The heritage of traditional agriculture among the Western Austronesians. Canberra: Australian National University. pp. 67-88

- 1995. Austronesian societies and their transformations. In P. Bellwood, J. Fox, and D. Tryon (eds.) The Austronesians: historical and comparative perspectives. Canberra: RSPAS, The Australian National University. pp. 214-228

—. 2000. Tracing the path, recounting the past: historical perspectives on Timor. In J. Fox and D. B. Soares (eds.) Out of the Ashes: destruction and reconstruction of East Timor. Canberra: ANU E Press. pp. 1-27

- 2002. Traditional Justice and the 'Court System' of the Island of Roti. International Conference on Traditional Dispute Resolution and Justice in East Timor, Dili.

Friedberg, C. 1989. Social relations of territorial management in light of Bunaq farming rituals. Bijdragen 145:548-562.

Groeneveldt, W. P. 1960. Historical notes on Indonesian \& Malaya compiled from Chinese sources. Djakarta: Bhratara.

Gunn, G. C. 1999. Timor Loro Sae: 500 Years. Macau: Livros do Oriente.

Hägerdal, H. 2006. Colonial rivalry and the partition of Timor. IIAS Newsletter 40: 16.

Hicks, D. 1990. Kinship and religion in Eastern Indonesia. Gothenburg Studies in Social Anthropology 12. Gothenburg: Vasastadens Bokbinderi AB.

Holthouse, K. and D. Grenfell. 2008. Social and economic development in Oecusse, Timor-Leste. Melbourne: Oxfam Australia and the Globalism Institute, RMIT University. http://tinyurl.com/6l2bg7d

International Crisis Group. 2006. Resolving Timor-Leste's crisis. Asia Report No. 120, 10 October 2006.

International Crisis Group. 2010. Timor-Leste: Oecusse and the Indonesian border. Policy Briefing: Asia Briefing No. 104, 20 May. Dili/Brussels.

Lach, D. F. 1965. Asia in the making of Europe. Vol. I (The century of discovery). Chicago: University of Chicago Press.

Leitão, H. 1948. Os Portugueses em solor e Timor de 1515 a 1702. Lisboa: Tip. da Liga dos Combatentes da Grannde Guerra.

Lieberman, V. 2003. Strange parallels: Southeast Asia in global context, c. 800-1830. Volume 1: Integration on the mainland. Cambridge: Cambridge University Press.

McWilliam, A. 2002. Paths of origin, gates of life: a study of place and precedence in southwest Timor. Verhandelingen van het Koninklijk Instituut voor Taal-, Land- en Volkenkunde 203. Leiden: KITLV Press.

—. 2003. Meto disputes and peace making: cultural notes on conflict and its resolution in West Timor. International Conference on Traditional Dispute Resolution and Justice in East Timor, Dili, East Timor.

—. 2005. Haumeni, not many: renewed plunder and mismanagement in the Timorese sandalwood industry. Modern Asian Studies 39(2): 285-320.

Meitzner Yoder, L.S. 2005. Custom, codification, collaboration: integrating the legacies of land and forest authorities in Oecusse enclave, East Timor. PhD Dissertation, Forestry and Environmental Studies. New Haven: Yale University.

- 2007a. Hybridising justice: state-customary interactions over forest crime and punishment in Oecusse, East Timor. The Asia Pacific Journal of Anthropology 8(1): 43-57.

- 2007b. The tobe and tara bandu: A post-independence renaissance of forest regulation authorities and practices in Oecusse, East Timor. In R. Ellen (ed.) Modern crises and traditional strategies: local ecological knowledge in island Southeast Asia. New York: Berghahn. pp. 220-237 
Metzner, J. K. 1977. Man and environment in Eastern Timor: a geoecological analysis of the Baucau-Viqueque area as a possible basis for regional planning. Development Studies Centre Monograph No. 8. Canberra: Australian National University.

Middelkoop, P. 1960. Curse-retribution-enmity as data in natural religion, especially in Timor, confronted with the scripture. Amsterdam: Drukkerij en Uitgeverij Jacob van Campen.

- 1968. Migrations of Timorese Groups and the question of the Kase Metan or overseas Black foreigners. In International Archives of Ethnography, vol. LI, pp. 49-142. Leiden: E. J. Brill.

Montalvão e Silva, J. C. 1910. A Mão D'Obra em Timor: breve memoria sobre o seu territorio, clima, producção, usos e costumes indigenas, industria, agricultura e commercio. Lisboa: Typographia "A Editora".

Neonbasu, G. 1992. Analisis sosio-budaya masyarakat ambeno, Timor Timur (eksposisi, dan telaahan kritis). In G. Neonbasu (ed.) Agenda Budaya Pulau Timor (2). Atambua, West Timor: Komisi Komunikasi Sosial Provinsi SVD Timor. pp. 66-103

Newitt, M. 2005. A history of Portuguese overseas expansion, 1400-1668, London: Routledge.

Oliveira, L. d. 1949. Timor na história de Portugal. Vol. I. Lisboa: Agência Geral das Colónias.

—. 1950. Timor na história de Portugal. Vol. II. Lisboa: Agência Geral das Colónias.

Ormeling, F. J. 1956. The Timor problem: a geographical interpretation of an underdeveloped island. Groningen and The Hague: J. B. Wolters and Martinus Nijhoff.

P. A. n.d. Timor. In Monografias das colónias Portuguesas: Cabo Verde, Guiné, S. Tomé, Angola, Moçambique, India, Macau, Timor; Separata do no. 21 do "Boletim da Agência Geral das Colónias. Pp. 137-151. Lisboa: Agência Geral das Colónias.

Palmer, L. and D. de Carvalho. 2008. Nation building and resource management: the politics of 'nature' in Timor Leste. Geoforum 39:1321-1332.

Panão, A. F. 1916. Timor: apicultura. Revista Colonial 4:160-161.

Parada, N. A. 1974. Timor. In Macau e a sua diocese, vol. X: Missões de Timor. M. Teixeira (Ed.), pp. 552-568. Macau: Tipografia da Missão do Padroado.

Pigafetta, A. 1969 [1522]. Magellan's voyage: a narrative account of the first circumnavigation. Vol. I. New Haven and London: Yale University Press.

Pinkaew Laungaramsri. 2000. The ambiguity of "watershed": the politics of people and conservation in Northern Thailand. Sojourn 15(1):52-75.

Ptak, R. 1983. Some references to Timor in old Chinese records. Ming Studies 17:37-48.

-. Editor. 1987a. Portuguese Asia: aspects in history and economic history (Sixteenth and Seventeenth Centuries). Stuttgart: Steiner Verlag Wiesbaden GMBH.

—. 1987b. The transportation of sandalwood from Timor to China and Macao c. 1350-1600. In R. Ptak (ed.) Portuguese Asia: aspect in history and economic history, sixteenth and seventeenth centuries. Stuttgart: Steiner Verlag Wiesbaden GMBH. pp. 89-109

Reid, A. 1988. Southeast Asia in the age of commerce, 1450-1680. Vol. I: The lands below the winds. New Haven: Yale University Press.

—. 1993. Southeast Asia in the age of commerce, 1450-1680. Vol. II: Expansion and crisis. New Haven: Yale University Press.

—. 1995. Humans and forests in pre-colonial Southeast Asia. Environment and History 1:93-110.

Roever, A. 2002. De jacht op sandelhout. De VOC en de tweedeling van Timor in de zeventiende eeuw. Zutphen: Walburg Pers.

Sa'u, J. P. 2002. Pelestarian hutan cendana: studi di desa bikekneno, kabupaten Timor Tengah Selatan. Magister Sains, Universitas Kristen Satya Wacana.

Schulte Nordholt, H. G. 1971. The political system of the Atoni of Timor. Verhandelingen van Het Koninklijk Instituut voor Taal-, Land-, en Volkenkunde, 60. The Hague: Martinus Nijhoff.

Teixeira, M. 1974. Pe. João dos Reis Martins. In Macau e a sua Diocese, vol. X: Missões de Timor. M. Teixeira (Ed.), pp. 249-257. Macau: Tipgrafia da Missão do Padroado.

Thomaz, L. F. F. R. 1974. Timor: notas histórico-linguísticas. Vol. II. Lisboa: Portugaliae.

Traube, E.G. 1986. Cosmology and social life: ritual exchange among the Mambai of East Timor. Chicago and London: University of Chicago Press.

Tsing, A. L. 2003. Cultivating the wild: honey-hunting and forest management in southeast Kalimantan. In C. Zerner (ed.) Culture and the question of rights: forests, coasts, and seas in Southeast Asia. Durham and London: Duke University Press. pp. 24-55

Vaquinhas, J. d. S. 1883. I: Timor. Boletim da Sociedade de Geographia de Lisboa 4:307-328.

Villiers, J. 1985. As derradeiras do mundo: the sandalwood trade and the first Portuguese settlements in the Lesser Sunda Islands. In East of Malacca: three essays on the Portuguese in the Indonesian archipelago in the sixteenth and early seventeenth centuries. Bangkok: Calouste Gulbenkian Foundation. pp. 59-90.

Wallace, A. R. 2000. The Malay Archipelago. Tenth edition. Singapore: Periplus.

Watt, G. 1908. The commercial products of India. London: John Murray. 


\begin{abstract}
The enclave of Oecusse-Ambeno, Timor Leste, was formed in part through struggles over controlling trade in sandalwood and beeswax, two forest products that continue to influence political and ritual allegiances, and the political history of Oecusse. These products are interwoven with the region's contacts with outsiders, influencing local political hierarchies and roles of kings, village heads, and ritual authorities. While wood and wax are recognized to be of Timorese origin, local myths posit that their use and value was unrecognized before the arrival of Chinese traders and Portuguese missionaries. Several narratives of the origins of trade in sandalwood, and the kings' annual beeswax candle tributes, illustrate the enduring connections among local authorities, forest resource control, religious symbolism, and ritual obligations surrounding harvests of sandalwood and beeswax. Customary practices contribute to forest conservation through local protection of beeswax-producing forests, and by circumscribing the harvest. While both beehives and sandalwood impede intensive agricultural land uses, farmers welcome beeswax as a profitable product that supports ritual. But they resent sandalwood's growth in their fields since it involves more regulation and increased labor requirements. The two products' different ecologies of disturbance and incidence contributed over time to distinct ownership norms and forms of control by customary authorities. This is the "political ecology of wood and wax" in Oecusse.
\end{abstract}

Key words: Oecusse, Timor Leste/East Timor, sandalwood, beeswax, customary authority, colonialism.

\title{
Résumé
}

L'enclave de Oecussi-Ambeno, Timor Leste, a été formée en partie par des luttes plus contrôler le commerce des bois de santal et de la cire d'abeille, deux produits de la forêt qui continuent d'influencer les allégeances politiques et rituelles. Ces produits sont entrelacées avec des contacts de la région avec l'extérieur, en influençant les hiérarchies locales et des rôles de rois, les chefs de village, et les autorités coutumier. Bien que le bois et la cire sont reconnus d'être l'origine timoraise, les mvthes locaux postulent que leur utilisation et leur valeur a été méconnue avant l'arrivée des commerçants Chinois et missionnaires Portugais. La cire d'abeille a été utilisée dès les années 1500 par l'église Catholique à fabriquer des bougies. L'histoire orale illustrer les liens durables entre les collectivités locales, le contrôle des ressources dans les forêts, le symbolisme religieux, et les obligations rituelles entourant les récoltes de bois de santal et de la cire d'abeille. Surtout, les pratiques coutumières de contribuer à la conservation des forêts grâce à la protection locale des forêts productrices de cire d'abeille, et en limitant la récolte. Bien que les ruches et bois de santal entraver l'intensification des terres agricoles, les agriculteurs de cire d'abeille accueillir comme un produit rentable qui soutient également leurs rituels. Mais ils sont fâchés à la croissance du bois de santal dans leurs champs, car elle implique une réglementation et en plus, des exigences du travail a augmenté. Les écologies différentes des deux produits ont contribué au fil du temps à des normes de propriété distincts et différentes formes de contrôle par les autorités coutumières. C'est «l'écologie politique du bois et de cire».

Mots clés: Oecusse, Timor Leste, bois de santal, cire d’abeille, l’autorité coutumiére, le colonialisme.

\section{Resumen}

El enclave de Oecusse-Ambeno, Timor Leste, fue formado en parte por los conflictos causados por el excesivo control del comercio de la madera de sándalo y la cera de abejas. Estos dos productos forestales siguen influyendo en la lealtad política y ritual, así como en la historia política de Oecusse. Estos productos se interconectan con las regiones del exterior, influenciando la política jerárquica local así como los roles de reyes, jefes de villas y autoridades de rituales. Mientras que la madera y la cera son reconocidas como de origen timorense, los mitos locales plantean que su uso y valor no eran reconocidos antes de la llegada de los comerciantes chinos y misioneros portugueses. Varios relatos de los orígenes del comercio de madera de sándalo, así como de los tributos anuales de vela hecha de cera de abeja a los reyes, ilustran las conexiones duraderas entre las autoridades locales, el control de los recursos forestales, el simbolismo religioso, y las obligaciones rituales que rodean la cosecha de madera de sándalo y cera de abejas. Las prácticas regulares contribuyen a la conservación de los bosques mediante la protección local a través de los productores de cera de abeja, y mediante la delimitación de la cosecha. Si bien las colmenas y madera de sándalo impiden el uso intensivo de la tierra agrícola, los agricultores dan la bienvenida a la cera de abejas como un producto rentable que apoya sus rituales. Sin embargo, han resentido el crecimiento de madera de sándalo en sus campos, desde que esto implica una mayor regulación y aumento en los requisitos de trabajo. Los dos productos tienen diferentes problemáticas e incidencias ecológicas debido a los largos modelos de propiedad y las formas de control ejercidas por las autoridades tradicionales. Esta es la "ecología política de la madera y la cera" en Oecusse.

Palabras clave: Oecusse, Timor Oriental y Timor Oriental, madera de sándalo, cera de abejas, la autoridad tradicional, el colonialismo. 